\title{
SENSE AND SENSIBILITY FILM: THE REFLECTION OF SOCIAL AND \\ CULTURE OF ENGLAND SOCIETY (1792-1797)
}

\author{
Andriadi \\ Tadris Bahasa Inggris \\ Fakultas Tarbiyah dan Tadris \\ Institut Agama Islam Negeri (IAIN) Bengkulu \\ Andriadi.Ambassador1@gmail.com
}

\begin{abstract}
Abstrak
Tulisan ini bertujuan untuk mengetahui: (1) sejauh mana transformasi film Sense and Sensibility karya Jane Austen merefleksikan kondisi sosial dan budaya masyarakat pada zamannya; dan (2) bagaimana penerimaan masyarakat (penonton) terhadap film ini. Penelitian menggunakan metode kualitatif (strukturalisme) dengan pendekatan sosiologi sastra. Hasil penelitian menunjukkan bahwa: (1) gambaran masyarakat Inggris pada tahun 1792-1797 tidak berbeda jauh dengan gambaran yang disuguhan film Sense and Sensibility, yaitu penerapan tradisi primogeniture. Tradidi ini memicu kaum laki-laki dan perempuan bersifat materialistis sehingga kualitas kebaikan yang dimiliki seseorang tidak akan menjadi pertimbangan yang baik pula dalam menemukan pasangan hidup karena kebiasaan masyarakat di sana menganggap uang, kedudukan, dan status sosial sebagai pertimbangan terpenting dalam mencari pasangan hidup; (2) film Sense and Sensibility memperoleh sambutan hangat oleh apresiator dari berbagai negara secara lugas sehingga dapat memberikan gambaran yang memadai mengenai 'popularitas' Sense and Sensibility sebagai film.
\end{abstract}

Kata Kunci: film sense and sensibility, cerminan sosial dan budaya, penerimaan masyarakat.

\section{Background}

Definitions of popular culture and pop culture often find different understanding. It is caused by the term "pop" comes from the word "populer". However, they have differen sense. The word "popular" is related to society, on the other hand, 'pop' was appealed from low class (Kayam, 2001, 83). Then, Kaplan (2009: 22) argued that popular art is not pop art. Pop art comes from low class art as the extent of artistic scoope, seeking and finding beauty from things that commonly regarded as bad things, or dig bad things from something that are 


\section{Al-lughah: Jurnal Bahasa}

regarded beautiful. On the other hand, MacDonal (2012:293) preferred using "mass culture" rather than "popular culture". He thought that "mass culture" is more accurate because it has clearer value. Culture is not only for mass consuming. Hence, high literature can be popular literature that had happened to Charles Dicken's work, G.A Enty, and Jane Austen. In the past, their works were high literature. When they were transformed in other media, they became popular; and came into popular fiction in the context of literature.

Film is one of populer fictions liked by people. Film studies have had many theories and methods. Storey (2006: 67) stated that film is learned in the point of "art", history that was showed as moments in "great tradition". Therefore, film is analyzed as important cultural industry for national identity. In addition, Adi (2011: 57) explained that characters have important roles in a film because through those characters, an idea or theme was dramatized. In other words, to understand a film, especially the story, it can be found through the characters' dialogues in the film.

The development of film is very significant that can give effects since many years ago, they have learned in the level of university and became subject of scientific research. The development of popular culture can not be avoided anymore in society, even this sometimes gives possitive or negative effects for society, good or bad quality, popular literature reflect society's need in daily life (Adi, 2011: 1). In other words, popular culture can be accepted by society as long as it can give enterainment and pleasure for audience.

Popular culture covers many genres of literature based on some characteristics. In this case, it is not important to discuss the kinds of genres because this research only focuses on popular romance film entitled Sense and Sensibility. It is the result of tranformation by John Alexander from Austen's novel with the same title. Jane Austen is a famous Britain author. Her works told about love, friendship, and romantic fiction. Sense and Sensibility is one of her novels that had been transformed in form of films many times. The productions of the films were in 1971, 1980, 1995, and 2008. Film Sense and sensibility which produced in 2008 was very popular in society in the world. This romance fiction 


\section{Al-lughah: Jurnal Bahasa}

told about ideal marriage because of wealth or financial. Because of its popularity, the film is reliable as material object in this research through sociology of literature research.

Research on sociology of literature is a study about relation between authors and their social life. Both genre and content, literary works will be formed by environment atmosphere and social power in a certain age (Endarswara, 2003: 78). In this study, popular literature is placed as sociology of literature study (Pramono, 2011: 41). Basically, Laurenson dan Swingewood (1971:104) proposed three perspectives related to sociology of literature, namely: (1) research that places literary works as social documents that contain reflection of situation at the age of the works were written; (2) research that investigates literary works as reflection of social situations of the authors; and (3) research that investigates literary works as manifest of historical events and the condiction of social culture. In this research, the researcher only used the first perspective to investigate the film Sense and Sensibility.

Based on the background above, the reseacher analyzed film Sense and Sensibility through sociology of literature approach. The main problems in this research can be formulated as the following questions: (1) in what extant the film Sense and Sensibility reflects social and cultural condition of its age?; (2) how do the audiences' responses toward the film?

\section{Sociology of Literature Theories}

Literary works are the authors' products that live in their own social environment. Sociology of literature approaches literary works by considering social aspects (Jabrohim, 2001: 169). It has an interest on literary works as social intuition created by authors as part of society. If so, literary work is an imaginative world of the authors that always related to their social life. Therefore, Grabsten argued that literary works often describe social facts that reflect sociological progress or show the changes of cultural characters (Darmono, 2004: 4) 


\section{Al-lughah: Jurnal Bahasa}

The goal is completely illustrate the relation among authors, literary work, and society. Wellek dan Werren (1993: 111) proposed three approches in sociology of literature, namely: first, sociology of authors, author as profession, and literature institution. The problems related to this point are basic economic in literary production, social background, author status, and author's ideology that can be seen from his/her activities outside of his/her works; second, the content of literary works, goals, and implisit things in the literary work itself and other social problems; third, readers and the social effects literary works. In this analysis, it used the second approach that covers: the content, goals, and implisit problems in the film related to social concerns.

Watt (1979: 3) spoke the relation among authors, literary work, and society. First, authors' social context - the relation between author's social position in society and relation between author's position in society related to readers' society; it is also included social factors that can influence the author's as individual. Second, literature as the reflection of society - how literary works can reflect the social condition in a certain society. Third, social function of literature - how a literary analysis that the value of the work related to the social and how the work has function to educate society. This analysis focuses on the second point - literature as the reflection of its society. In what extent film sense and sensibility can be as the reflection of society condition at the age.

In addition, Junus (1986: 3) stated that in doing sociology analysis on literary works can apply three approaches, namely: first, literary work is placed as socio-cultural document that reflects its age (Sociology of text); second, the status of author in their environment (Sociology of author); third, the readers' audience toward the works (sociology of reader). This analysis only focuses on the first and second approacher, namely: film Sense and Sensibility as socio-cultural document in its age and readers' responses toward the film.

\section{Research Method}

This research is a textual analysis where the researcher places films as texts without discussion technique aspects in the films. As Klarer (2004: 56) explained 


\section{Al-lughah: Jurnal Bahasa}

that film idiosyncratic model of presentation - such as camera angle, editing, montage, slow and fast motion - parallel features of literary texts or can be explained within a textual framework. When a film is placed as a text, analysis method refers to structuralism because it treats literary works as accumulation of elements totally (Storey, 2006: 67). By this way, the elements can be understood as total integrity of literary works.

Structuralism, as method in popular fiction research, is concerned to convention in society related to the fiction. When a researcher criticizes a popular fiction, the researcher concerns in the area of convention. The structuralism intention is to define the condition which causes the fiction appears, analizes the belief system of society, thought, conception, and idea which enable to create literature product are important aspectsto analyze (Adi, 2011: 141). Context of popular fiction in structuralism studies also means analyzing the belief system, culture, and thought which underlies popular fiction appears. Culler (1975: 4) said that structuralism is thus based in the first instance, on the realization that if human action and production have a meaning there must be an underlying system of distinction and convention which makes meaning possible.

Films Sense and Sensibility produced by Anne Pivcevic in 2008 directed by John Alexander was used as object materials in this research. The data in this study can be in form of dialogues, narrations, or pictures - which concerned to social and cultural reflection of the age. The film was placed as social documents that contained reflection of situation at the age of the works were written. In collecting the data, the researcher divided the films into contiguous fragments. Then, the fragments were analyzed by sociology of literature approach in order to find the reflection of social and culture. Then, to get the audiences' responses, the researcher would review some audiences' responses toward the film that they stated in printed or electronic media. 


\section{Al-lughah: Jurnal Bahasa}

\section{Synopsis Film Sense and Sensibility}

When Henry Dashwood died, he left all his wealth to John Dashwood, his first son from the first wife. Meanwhile, his second wife and three daughters (Elinor, Marriane, and Margarete Dashwood) were without home and little income. Mrs. Dashwood then accepted an offer from a distant cousin, Sir John Middleton, who has heard of her bad situation. With her daughters, she moved to a small house in Barton Park, located in Devonshire. At the beginning, Elinor was very sad of leaving their house in Norland. Because her closed relation with Edward Ferras, she can forget her unhappy memory. In Borton Park, Elinor and Marrian met many new friends, included Colonel Brandon and Willoughby, who saved Marriane when she got accident. They fell in love, but Merrian was suffering from aparting from Wiloughby who must go to London for business. While Anne and Lucy Steel made relation with Mrs. Jennings who arrived in Barton Park as guests in Middleton's family. Lucy approached Elinor and told her that she had secretly engaged with Edwar Ferras. Elinor thought that Lucy engaged with Robert. She shocked and distressed knew the fact that Lucy had engaged with the man she loves, Edward Ferras. Finally, Lucy decided to merry twith Robert because he will get the wealth of Ferras' family. Then Edward proposed Elinor, and Colonel Brandon also engaged with Marriane. The couple lived togather in Delaford and had good relation with their step mother and step brothers in Barton Cottage.

\section{Analysis and Discussion}

\section{Social and Cultural Illustration of Britain's Society $1792-1797$}

In 1792 - 1797, Britain's society lived in social system that tended to materialistic because their activities were influenced by social system at that time claled primogeniture. Social classed divided into upper-gentry, pseudogentry, traders, and lower-gentry. The social classes were got from family background, education, and wealth. The highest class was used to be rich technocrates who have hectars of land. To maintain their properties and manage their family, they spent much money to pay servants. The servants got 


\section{Al-lughah: Jurnal Bahasa}

some facilities from private bedroom, clothes, medical treatment, and salary. Female servants were used to be reponsible to manage house: cooking, washing, dity up house, and other house works. On the other hand, male servants were used to be responsible to be the head of servants, gardener, cart men, footmen, or farmhands.

In this age, social system related to heritage applied primogeniture culture, a traditional tradition where legally the oldest son got all of his family's wealth. This tradition signs that the oldest son ignored the rights of his younger brothers and his sisters because giving heritage was based on seniority in family. This tradition supports materialistics, especially for women in finding their their couple. Love was not the first consideration in choosing life couple. However, social class, money, and dignity are the priority to determine quality of life couple. By getting marriage with the oldest son in his family, it can quarantee the woman's life and reputation in society.

Most men got married at the age 27-30 years old. Similiar to women, men got merried for love was as necessary as merried because money. The men who were not the oldest son in their families tried to find and merried a woman with a big amount of dowry. They tended to find woman from high class family (upper-gentry). The woman could get merried at the age of 22 years old, and they were regarded as old girl at the age of 30 years old. For upper-gentry woman, marriage is one of proposition of bussiness, a dowry from woman was an important determinant in a merriage because a husband would provide her needs like a servant, baby sitter, and help house works like a servant. In short, both man and woman (who are not the oldest in the family) tended to be materialistic in choosing couple to improve or mentain their social class in society.

\section{Social and Cultural Analysis in Film Sense and Sensibility}

The reflection of culture in film Sense and Sensibility is the application primogeniture tradition and britain's society life that tended to be materialistic, 


\section{Al-lughah: Jurnal Bahasa}

especially in choosing their couple. This case can be explained as the following details:

\section{a. The Application of Primoganiture Tradition}

Primoganiture tradition has been shown from the beginning of the film. Henry Dashwood died and gave all wealth to his first son, John Dashwood. On the other hand, his three daughters only got inpermanent house and very little money. This condition made them moved to Barton Park, and left Norland. It can be seen from the following dialogues:

Merry Dashwood : : John, I'm glad you've come.

Henry Dashwood : Is it John?

John Dashwood : : Here I am, father.

Henry Dashwood : : The law prevents me from dividing up my estate. You are to have everything. Without your help, your stepmother and the girls will have almost nothing. You must do something. You must promise me. You must give me your solemn promise.

John Dashwood : : Yes, of course. I promise.

This dialogue happened when Henry Dashwood would die. It explained that after his death, all his wealth would legally be inherited to his first son, John Dashwood. Although they have known about this tradition, his father asked him to take care of his step mother and his three step sisters. It is clear that primoganiture tradition was applicated in a real life in this age in Britain. Another dialogues that indicate the applicationof this tradition can be as follows:

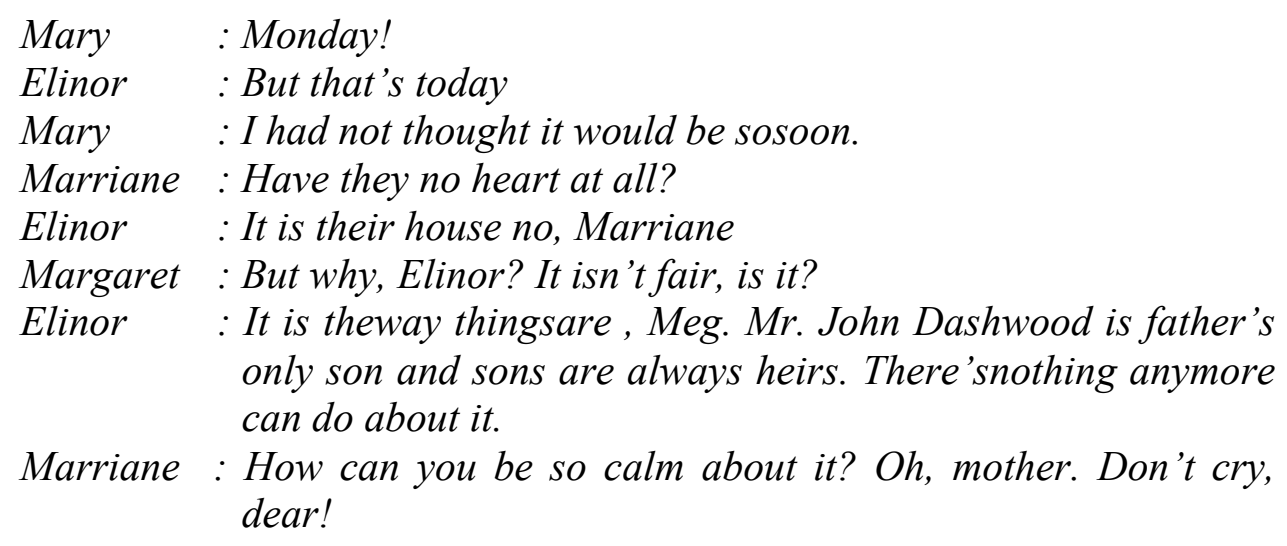




\section{Al-lughah: Jurnal Bahasa}

The dialogue above indicates that Elinor as the oldest daughter in Dashwood family has understood about the primogeniture sytem where a father died, all of his wealth otomatically was inherited to the oldest son. This system obtained legally. It can be seen as the following dialogue:

John : I thought of giving the girls $£ 1,000$ a piece. Would that be fair do you think?

Fanny : £ 1,000 a piece? Are you mad?. Do you rob your only child of his rightful inheritance? Henry, your father proposes to steal $£ 3,000$ from you to give to his half-sister.

The dialogue above showed that Fanny tried to remind her husband not to spend to much time to suppor his three step sisters because she thought that her first son has right to inheritethe wealth as the next inheritance in Dashwood family.

Based on the detail analysis above, it showed that film sense and sesibility reflected clearly about the application of primogeniture tradition in managing family heritage where only the oldest son in family got the wealth after the father died.

\section{b. Marriage Mased on Material and Social Class}

Film Sense and Sensibility is basically discussed the things related to ideal marriage based on their idealism at this era. However, the ideal marriage described in the film tended to a kinf of marriage based on consideration of money, honour/position, and social status in society. Some concept of ideal marriage proposed by some couples in this film:

\section{(1) Marrianne Dashwood and Colonel Brandon}

In this film, Marriane Dashwood is a character that appealed to 'sensibility' quality. This 17-year-girl flared up with emotion, spontanity, deep in heart, too believe in loyality in love, and she has romantical idealism. Those made her fell in love with a boy named Willoughby.

Colonel Brandon is a 35-year-pensioner of police who makes friend with John Middleton for long time. He fell in love with Marriane Dashwood. He approched the family by doing good things and friendly 


\section{Al-lughah: Jurnal Bahasa}

to Dashwood Family. Colonel Brandon fell in love at the first sight with Marrian. HE was very impressed when saw her played piano during dinner party in John Middleton's house. Marriane reminded him to a woman in the past who he loved very much.

When Mrs. Jenning told Dashwood family that Colonel Brandon loved Marriane; she refused strictly because she thought that the Collonel was too old for her, and he was really far from her dream of romatical idealism. However, the family was really supported Marrian with Colonel Brandon, especially mother and Elinor because Colonel Brandon is a man with everything.

Marriane : And is this what everybody thinks? How mortifying Elinor! Elinor : You like him, Marrian?

Marriane :Yes, but because he's the only person in the neighbourhood without whom one can have an intelligent conversation. I never thought he meant. Elinor, he is too old.

Mrs. Mary : He is 35, Marriane, 5 years younger than I am. And I never thought of myself as being descrepit.

Marriane : That's unfair, mama. You know I never meant that.

Mrs.Mary : Most people, I think, would still consider Colonel Brandon a young man. No-one's forcing him upon you, my dear, but men of 35 have merried girls of 17 before, I belive.

Marriane : You do both realize it will be impossible for me to speak him again? Except in company.

It shows that Mrs. Merry tried to make sure her 17-year-daughter that having a much older man as a husband was not a big problem as long as he has enough material to support life.

After refused Coloner Brandon as her husband, Marriane met a boy named Willoughby. They firstly met with great impression that made them fall in love with strong feeling. Marriane's relation with Willoughby made her sister, Elinor worried that Colonel Brandon will loose his love that he has shown to her sister, Marriane. Elinor was so dissapointed that Marriane showed her romantic relation. She was as if praised Willoughby very much. Marriene showed her dissapointed when Wiloughby permited to go back to London for business, and he won't be 


\section{Al-lughah: Jurnal Bahasa}

back for some years. In a moment, she felt strange and stress when she met Wiloughby in a party in town. Wiloughby seemed to avoid her, and he was speaking with another young girl. Marriane approached him, and he reponded her without interest. It was really different from his previous manner to her. Finally, Marrian knew that the woman is his nobel wife. HE married him because of wealth. Marriane broke her heart and decided to marry Colonel Brandon, the man who really admires her.

\section{(2) Elinor Dashwood and Edward Ferras}

Elinor Dashwood is a character that proposes 'sense' quality in this film. It can be seen from her social responsibility toward other characters. This 19-year-girl can pretend or hind her feeling to Edward Ferras. Their love lived in their heart started from their first meeting in Norland. Edwar is the candidate of inheritance from a such rich father. However, his candidate of wife will be determined by his mother's want. His mother and sister wanted Edward get a high class woman, a woman with prestigious social status. It can be seen from the following dialogue:

Fanny : Stay amoment if you would, Mary! I just wanted to give you alittle hint about my brother, Edward.

Mary : I think he is enjoying his visit, Fanny.

Fanny : You must know that my mothe, Mrs. Ferras, has very high hopes of him.

Mary : I'm sure he will fulfil them.

Fanny : Both in terms his career until married. He will be expected to marry a young lady ither ofhigh rank or great fortune, preferably both.

Mary : I see

Fanny : His happiness will depend upon our mother's wishes. If he goes against her, he will get nothing. So, you see, any young women who tries to draw him in will find herself gravely disappointed. Just a little hint, Mary.

Mary : Thank you, Fanny. I'm much obliged to you.

Fanny, Edward's elder sister, and his mother really wanted Edward marries a high status woman. On the other side, Edward is a man that really wants to have a girl with simple life. He wants a simple woman who 


\section{Al-lughah: Jurnal Bahasa}

can make him comfortable and really loves him. Wealth and social class are not important considerations for him in choosing a wife. It indicates that materialistic can be supported from parents and family members, especially mother and sisters in this age. Their desire to get more welth from marriage influences the man's decision to select wife in this age.

\section{(3) Lucy Steel and Robert Ferras}

Lucy Steel is a girl with various tricks and has a selfish and unstable soul. She got engage secretly with Edward Ferras for four years. This relation is only a result of youth's stupidity, not based on a true love. Lucy did not marry with Edward soon at that time because it was a stupid decision. She must wait until Edward got his father's wealth (Ferras' Family wealth). Finally, Lucy married with Robert Ferras, Edward's youngest brother. Their marriage was only based on material because Robert got all wealth of Ferras's.

\section{(4) John Willoughby and Sophia Grey}

John Willoughby is a charming boy, but a liar. HE can grab Marriane's deep heart but leave her for getti another girl's wealth, Sophia Grey. Willoughby never loves his wife because Marriane is always in his heart. He married his wife only for wealth, not for true love.

Based on the analysis above, it shows that most of discourse proposed by film Sesnse and Sensibility is related to certain social classes, namely: uppergentry (technocrates), pseudo-gentry, traders, and lower-gentry. However, the opposition of Dashwood's family lied between of them. This film shows that good value that they have will not become a consideration in choosing life couple baucause it has became tradition of the society in this age that money, honour, and social status as the most important consideration to get a life couple. 


\section{Al-lughah: Jurnal Bahasa}

\section{The Audience's Responses toward Film Sense and Sensibility}

Literature studies in the context of populer literature analysis can not be aparted from audience's responses toward it. The analysis will give clear description about "popularity" film Sense and Sensibility as a work, in this case as a film. In this part, it discusses on audience's responses toward Sense and Sensibility as film.

Screenplay of Sense and Sensibility was transformed into film in some years: 1971, 1980, 1995, and 2008. This fact has proved that Sense and Sensibility as film was succesfully accepted by society in the world. This analysis chose Film Sense and Sensibility produced by Anne Pivcevic in 2008 directed by John Alexander. At the premier of the film in 2008, it got great reponses from the apreciators from different countries. Besides it has good quality in the content, the udiences have been bored to horror, semipornography, and comedy that showed many physical stupidity and pornography. Film Sense and Sensibility proposed fresh revolution in more realistic frame presented by beutiful actresses and handsome actors.

The premier of the film attracted 5.54 millions of audiences in Britain. The second one, it attracted 5.74 million audiences, and the next one became 6.76 audiences (http:// Sense and Sensibility TV miniseries cite note-SixJan-45). This fact proved that the audiences were so antusiast in watching the film.

Responses toward this film wa also conducted in newspaper, other printed media, electronic blog. One of them was blog Jenaite (Jenaite is a comunity which focuses on the life of Austen as the author of the novel, the novels of Austen, and variois kinds of adaptation of films from novel on television).

In printed media, it was found in Western Mail (January 3, 2008), The Guardian Media Group (January 3, 2008), Telegraph Media Group (January 5, 2008), Manchester Evening News (January 8, 2008), The Brimingham Post (January 13, 2008), USA Today (April 1, 2008), The New York Times (April 5, 2008), dan Association Newspapers (April 5, 2008). Electronic Media can be found in $B B C$ News (April 2, 2008). Some the result of independent interview, namely: Andrew Davis (screenplay writer of Sense and Sensibility) and Dan 


\section{Al-lughah: Jurnal Bahasa}

Stevens (Actor played as Edward Ferras in film Sense and Sensibility). Then, the information will be completed by the members of Janeite community. In this analysis shows only some reponses to represent audience's reponses toward the film.

Eric in his response entitled "Accurate History" (Western Mail, January 3, 2008), through his article stated that he liked the film adaptation very much. He could compare the film adaptation with the novel, but all hictorical aspects seemed accurate. He loved all sceneces and all actors played their characters totally, even he said that Wiloghby was really total ion his character. He also praised for the beautiful setting. Then, love scences in the beginning story were wonderful because they did not ruin surprises in every characters.

Linda in her response entitled "Criticism with the Mother" (The Guardian Media Group, January 3, 2008) said that this film was really worth to discuss because it was exclusive. However, she did not admire in Mrs. Marry Dashwood character (The mother of Elinor and Marriane). She hoped Mrs. Mary needed to be more romantic and using her feeling in reacting her daughers and brothers in law. She stated that although she had watched the film, she has not read the novel.

Melinda Houstondi in her response entitled "A Gorgeous Adaptation of her most Frivolous Work" (Telegraph Media Group, January 5, 2008) stated that Sense and Sensibility is a gorgeous film adaptation from a common novel. And all beauty came from a great process of film making and a great screenplay.

Enny Ann in her response entitled "The Locations, Costumes and Acting are Excellent" (Manchester Evening News, January 8, 2008), stated that setting, costume, and acting of actors and actresses in this film were perfect with romantic aspects. This film was a really honest and realistic potrait of England in this age.

Ginia Bellafante stated her response in The Brimingham Post on January 13, 2008. She said that there was no significant mistake in film Sense and Sensibility in this version which was an eternity reward to Jane Austen's. All scences run well. This film changed emotional chemistry. As the result, this adaptation was enjoyable aand avoid being boreness of audiences. 


\section{Al-lughah: Jurnal Bahasa}

Nancy Banks-Smith stated her response in USA Today on April 1, 2008. She state that Sense and Sensibility proposed spontanous and smart story, from the casting till each scences were amazing. Davies and the director John Alexander were freely explored their skills on each scences that made it different from what Austen did as the authorof the novel, such as: the strong image of Brandon, the most facinated Wiloghby in getting Marriane's interest, elegan temptation of Wiloughby, Elinor who has very good at control her emotion and desire, Edward who is difficult to understand. All things proposed perfectly and really amused the audiences.

Serena Davies stated her response in The New York Times on April 5, 2008. She was really appreciated this film since she watched at the first time. She felt that this film was the soul of the novel. It was really competent and became the best film Sense and Sensibility rather than other versions that had been played in the previous years. This film really has briliant competency where the amazing costumes support the film very much.

The responses above describes the "popularity" Sense and Sensibility as film. The film got positive responses from the apreciators from many countries.

\section{Conclusion}

The series of analysis on film Sense and Sensibility and the illustration of social and culture of England in 1792-1797 above shows that the application of primogeniture tradition encouraged men and women became matrealistic especially in choosing their couple where money, social position, and social status became the most important considerations. Then, the description of England's society in the film was not really different from a real situation at the age, where the quality of someone's kindness will not become good consideration in finding life couples because the society's strotype only considered money, social position, and social status as the most important consideration to choose life couples. Furthermore, Film Sense and Sensibility produced in 2008 got great responses from audience that gives clear illustration about the 'popularity' of Sense and Sensibility as film. 


\section{Al-lughah: Jurnal Bahasa}

\section{References}

\section{Books and Articles}

Adi, I.R. (2011). Fiksi Populer: Teori dan Metode Kajian. Yogyakarta: Pustaka Pelajar.

Darmono, S.J. (2009). Sosiologi Sastra Suatu Pengantar Ringkas. Jakarta: Pusat Pembinaan dan Pengembangan Bahasa.

Endraswara, S. (2003). Metodologi Penelitian Sastra: Epistemologi, Model, Teori, dan Aplikasi. Yogyakarta: Caps.

Junus, U. (1986). Sosiologi: Persoalan Teori dan Metode. Kuala Lumpur: Dewan Bahasa dan Pustaka Kementrian Pengajaran Mahasiswa.

Kayam, U. (1981). Seni, Tradisi, Masyarakat. Jakarta: Sinar Harapan.

Klarer, M. (2014). An Introduction to Literary Studies. London: Rouledge .

Laurenson, D \& Swingwood, A. (1971). The Sociology of Literature. London: Granada Publishing Limited.

McDonald, D.(1962). Theory of Mass Culture. New York: Holt, Reinhart \& Winston.

Storey, J. (1996). Cultural Studies dan Kajian Budaya Populer: Pengantar Komprehensif Teori dan Metode. Yogyakarta: Jalasutra.

Wellek, R \& Werrent, W. (1989). Teori Kesusastraan. Terjemahan Melani Budianto. Jakarta: Gramedia.

\section{Printed and Electronic Media}

Ann, E. "The Locations, Costumes and Acting are Excellent". Manchester Evening News published on January 8, 2008.

Austen, J. (2008). Sense and Sensibility. John Alexander (Director). England: Anne Pivcevic.

Banks-Smith, N. USA Today published on April 1, 2008.

Bellafante, G. The Brimingham Post published on January 13, 2008.

Davies, S. The New York Times published on April 5, 2008. 


\section{Al-lughah: Jurnal Bahasa}

Eric. 'Accurate History'. Western Mail published on January 3, 2008.

Houstondi, M. "A Gorgeous Adaptation of her most Frivolous Work". Telegraph Media Group published on January 5, 2008.

Jack, M. Retrived on August 31, 2019 from (http:// Sense and Sensibility TV miniseries cite note-SixJan-45).

Linda. "Criticism with the Mother". The Guardian Media Group published on January 3, 2008. 